Andrej Bertoncelj ${ }^{1}$

UDK 65.012.4(497.4)

Preliminary paper

Prethodno priopćenje

\title{
MANAGERS' COMPETENCIES FRAMEWORK: A STUDY OF CONATIVE COMPONENT
}

\begin{abstract}
This paper aims to study the conative component of competencies of managers in the posttransition economy of Slovenia. A conceptual framework of the tripartite components of competencies is developed and a sample of 183 managers in 11 small and medium enterprises from different sectors of industry is analyzed. The eventual disparity with the managers ' conative component of competency and their job-related self-expectations and level of adaptation is analyzed. The results of the study suggest that Slovene managers are not aggressive initiative-takers but do not resist opportunities when they arise. However, the conative component of managers reveals that they might have problems coping with market and economic challenges because they will most likely shy away from taking the initiative in finding new opportunities.
\end{abstract}

Key words: Conation, Tripartite components of competencies framework, SME, Middle managers, Slovenia.

JEL: $J 24, M 13$

\section{INTRODUCTION}

In human resources management (HRM) the concept of individual competence is widely used, however, determining a precise definition is still a matter of much discussion. Some scholars (Boyatzis, 1982; Schroder, 1989; Burgoyne, 1993) refer to the set of skills that an individual must possess in order to be capable of satisfactorily performing a specified job. Competence is, according to Mansfield (1999), Ruth (2006) and Yang et al. (2006), the underlying characteristic of a person that results in an effective or superior performance. There is not a single factor, but a range of factors that differentiate successful from less successful performance, including personal qualities, motives, experience and behavioral characteristics (Boyatzis, 1982).

According to Winterton et al. (2005), competence-based HRM has become widespread phenomenon and competence has gained a much broader conception, including knowledge and skills, alongside the behavioral or psycho-social characteristics. For the purposes of this article we use "competence" as a general ability and "competencies" as components of competence (Hoffman, 1999; Garavan and McGuire, 2001). We concur with Mulder and Collins (2007) who claim that competence can be viewed in a holistic or professional development orientation and competencies as components of competence. If the term competency is used, it means a more specific, behavioral or behaviorism-oriented perspective (McClelland, 1973 and 1998).

The interest of this paper is competencies as individual characteristics in management. Many scholars have studied competencies as individual characteristics (Baker et al, 1997; Ellström, 1997; Cheetham and Chivers, 1998; Selby et al., 2000; Sandberg, 2000; Mulder,

\footnotetext{
${ }^{1}$ University of Primorska, Slovenia, Associate Professor and Associate Dean

Email: andrej.bertoncelj@fm-kp.si
} 
2001; Boon and Van der Klink, 2001; Armstrong, 2003; Liu et al., 2006; Draganidis and Mentzas, 2006; Biloslavo and Lynn, 2007; Mlinar et al., 2009; Videmšek et al., 2010).

However, despite numerous papers written about competencies, the managerial challenges in transition economies of Central and Eastern Europe are given little attention. Therefore, our research question is whether managers in Slovenia have competencies such as opportunity perception, creativity, innovation, risk taking ability and initiative that would allow them to cope efficiently with changing business environment, which is characterized by increasing complexity, uncertainty and discontinuity (Chung et al., 2006; Patel, 2007; Dolenc, 2010). For the investigation of the question, a model of tripartite components of competencies is set: cognitive, affective, and conative ones, with focus on the conative component of competencies as the most stable and unchangeable one.

The paper is organized as follows. The next section addresses components of competencies and their assessment. It is followed by an explanation of the research methodology, sample and findings. The final section discusses the limitations of our study, future research opportunities and conclusions.

\section{THE TRIPARTITE COMPONENTS OF COMPETENCIES FRAMEWORK}

An individual's value system is composed of cognitive, affective and conative components, which all result in certain behavior and acquisition of these components is an on-going process (see Figure 1). The cognitive component of competences can be learned and the affective component of competences can be acquired through the process of professional socialization; the conative component of competences is inborn and can only be fostered (Kovač and Bertoncelj, 2008).

Cognitive part is commonly connected with intellectual abilities and intelligence. Intelligence has been studied as a predictor of performance and different taxonomies about types of intelligence have been developed (Grigorenko et al., 2000; Rogoff, 1990; Earley and Ang, 2003).

Figure 1

Tripartite individual competency components construct

\begin{tabular}{|c|c|}
\hline \multicolumn{2}{|c|}{ Competency } \\
(as measurable personal characteristic) \\
\hline Cognitive component & Affective component \\
Knowledge, skills & Emotional flexibility \\
\hline $\begin{array}{c}\text { Conative component } \\
\text { (volitional steering of action } \\
\text { toward some goals) }\end{array}$ \\
\hline Base on individual`s value system \\
\hline
\end{tabular}

Result in performance oriented behavior

Source: Author 
Winterton et al (2005) claim that specialized cognitive competencies are prerequisites for superior performance in a particular activity, whether defined narrowly (e.g. solving second order differential equations) or broadly (e.g. analytical competence). Another antecedent of presented tripartite competency model is affection, which can not avoid the question of personal traits. Personal traits include biological determinants (such as temperament), motives (such as achievement motive) and generalized attitudes and beliefs (such as generalized self-efficacy). Cognitive and affective parts of personality are most commonly cited in competency discussions.

However, from the point of view of practitioners, what counts is action: how someone will act, will not act, or is preparing to act. Or to put in other words: the cognitive and affective parts of a person's mind have to be realized in certain action. Though both the cognitive and affective sides are clues to performance, they do not necessarily have an effect in action. Therefore, we are interested in researching how a person will act. We argue that, besides the soft component of competencies (the affection side of the mind), and the hard component of competencies (the cognitive side of the mind), the conative component of competencies (the conative side of the mind) should be included in the concept.

Conation is an emerging concept defined as the use of will or the freedom to make choices about what to do (Kane, 1985; Mischel, 1996) as a proactive aspect of behavior (as opposed to reactive or habitual), which is the personal, intentional, deliberate, goal-oriented, or striving component of motivation (Baumeister et al., 1998; Emmons, 1986), as the tendency to take and maintain purposive action or direction toward goals (Snow et al., 1996) and as the achievement aspect of ability, the process through which we fulfill our goals (Kolbe 1997). To summarize several definitions, conation is described as volitional steering of action toward some goal. As such, conative competency is an important part of the tripartite competency dichotomy which is not teachable.

There is increasing concern about what motivates people in a job. Every individual has some expectations about the organization he/she work for and vice versa. An individual has job-related self-expectations, which have an influence on his performance. Kolbe (1997) claims that strain occurs when an individual tries to live up to false self-expectations. Expectancy theory (Vroom, 1964) suggests that motivation is based on values and beliefs of individuals, or on how a person feels about effort, performance, and outcomes.

To achieve the main research objective, the study attempts to seek answers to the following hypothesis:

H1: Managers in Slovenia are not aggressive risk takers and can have troubles to cope efficiently with a recession.

H2: A disparity between managers' conative component of competency and managers' job-related self-expectations and level of adaptation exists.

\section{RESEARCH METHODOLOGY}

We present here the assessment tools, sample structure, data analyses and findings followed by the final discussion.

\section{Assessment of conative component of competency}

Kolbe (1997) developed the Kolbe ${ }^{\mathrm{TM}}$ Index, which identifies four conative modes (Kolbe Action Modes $\left.{ }^{\circledR}\right)$ through which we act, albeit with different intensity. The four conative Kolbe Action Modes ${ }^{\circledR}$ can be determined with the Kolbe $\mathrm{A}^{\mathrm{TM}}$ Index:

- FF - Fact Finder (instincts to probe, refine and simplify),

- FT - Follow Thru (instincts to organize, reform and adapt), 
- QS - Quick Start (instincts to improvise, revise and stabilize),

- IM - Implementer (instincts to construct, renovate, and envision).

The degree of intensity each individual has in an Kolbe Action Mode ${ }^{\circledR}$ is defined on a scale from 1 to 10 and each mode has three Zones of Operation on a scale from 1 to 10: the Preventive Zone (1-3 on the scale), in which one prevents problems through its use; the Responsive Zone (4-6 on the scale), in which one acts in an accommodating way; and the Initiative Zone (7-10 on the scale), in which one initiates solutions. The Kolbe $\mathrm{A}^{\mathrm{TM}}$ Index is a forced-choice instrument that requires subjects to choose two answers from four response choices reflecting how they would most and least likely respond to 36 single-sentence problem-solving or behavioral scenarios (for more details see Kolbe 1997, 1999, 2003).

The decision to use the Kolbe ${ }^{\mathrm{TM}}$ instrument as a tool for measuring the conative component of competencies was made on the basis of reliability and validity, for which Kolbe (2003) provides a strong argument, claiming that this instrument is considered valid and reliable in predicting performance. The decision to use the Kolbe ${ }^{\mathrm{TM}}$ instrument was also made because it measures the above-mentioned and most cited conative side of managerial antecedents, i.e. the conative component of competencies.

Kolbe (1999) defines in the QS Kolbe Action Mode ${ }^{\circledR}$ the following natural advantages: promoting appropriateness, improvising presentations, converting data, challenging the status quo, revising standards and changing priorities. An individual who scores highly (7 to 10 ) in the Quick Start Kolbe Action Mode ${ }^{\circledR}$ will most likely succeed at tasks which require an individual to invent, brainstorm, originate, devise, challenge, contrive, risk, play, reform, improvise, promote and intuit. An individual who scores highly (7 to 10) in the Fact Finder Kolbe Action Mode ${ }^{\circledR}$ will most likely succeed at tasks which require an individual to probe, research, formalize, allocate, deliberate, priorities, define, prove, specify, calculate, inquire, and evaluate. On the other hand, an individual who scores highly (7 to 10) in the Follow Thru Kolbe Action Mode ${ }^{\circledR}$ will most likely succeed at tasks which require an individual to structure, consolidate, translate, prepare, discipline, coordinate, arrange, integrate, schedule, plan, budget, and chart; and an individual who scores highly ( 7 to 10) in the Implementer Kolbe Action Mode ${ }^{\circledR}$ will most likely succeed at tasks which require an individual to form, mould, demonstrate, craft, shape, put together, build, render, construct, fix, repair and practice (for more details see Kolbe 2003, 4).

The Kolbe $\mathrm{B}^{\mathrm{TM}}$ Index, meanwhile, measures an individual's job-related selfexpectations and level of adaptation (Kolbe 1997). When an individual tries to live up to false self-expectations, strain occurs. Strain is one of the measures of conative stress. Strain on the job is identified by comparing Kolbe $\mathrm{A}^{\mathrm{TM}}$ Index results to Kolbe $\mathrm{B}^{\mathrm{TM}}$ Index results. Conative strain occurs when there is a difference of four or more between Kolbe $\mathrm{A}^{\mathrm{TM}}$ Index and Kolbe $\mathrm{B}^{\mathrm{TM}}$ Index results in any mode.

Conative stress can be measured through conflict, strain, and tension (Kolbe, 2004). Conflict occurs when two people with contradictory instincts interrupt each other's progress by insisting on their own paths to problem solving. Potential conflict is identified by comparing their Kolbe $A^{\mathrm{TM}}$ Index results (the individual's conative reality). Kolbe claims that there will be stress between people working directly with one another if they have a difference of four or more in any mode (Kolbe, 1997). Strain on the job is identified by comparing Kolbe $\mathrm{A}^{\mathrm{TM}}$ Index results to Kolbe $\mathrm{B}^{\mathrm{TM}}$ Index results (an individual's job-related selfexpectations). For the purposes of this study, strain was measured if there was a difference of four or more between Kolbe $\mathrm{A}^{\mathrm{TM}}$ Index and Kolbe $\mathrm{B}^{\mathrm{TM}}$ Index results in any mode. Tension occurs when external obstacles posed by people or circumstances force an individual to work against his instincts. Tension is identified by comparing the Kolbe $\mathrm{A}^{\mathrm{TM}}$ Index results to the Kolbe CTM Index results (job requirements as determined by someone else, usually a boss or 
supervisor). According to the Kolbe Corporation, there is no bias in gender, age, race, or national origin in Kolbe instrument results (Kolbe Corporation, 1999).

\section{Sample}

The studied sample was chosen in a random manner in different sectors of Slovene industry (cutting, shaping and finishing of ornamental and building stone; forging, pressing, stamping and roll forming of metal; powder metallurgy; manufacturing of glass and glass products; low electricity diodes technology production; manufacturing of other fabricated metal products; cargo handling and storage; hardware consultancy; business consultancy; and hospitality and tourism). Out of that, ten companies were mid-sized enterprises and one company was a small enterprise. Six of the companies were founded after 1990 and the other five were restructured and privatized after 1990. One hundred and eighty-three managers participated in the Kolbe testing. Out of that, one hundred and seventy-five managers were middle-managers and eight managers were top-managers. The sampling was purposive in that only managers were involved. Eighteen managers were excluded because their result was "In Transition", meaning that, due to reasons on the individual level, their natural talents could not be revealed. Not all of them concluded the Kolbe $\mathrm{B}^{\mathrm{TM}}$ test, which has to be taken into consideration when interpreting the results.

\section{Data Analyses}

Descriptive statistics is presented in Table 1.

Table 1

Descriptive statistics

\begin{tabular}{|l|c|c|c|c|c|c|c|c|}
\hline & \multicolumn{2}{|c|}{ FF } & \multicolumn{2}{c|}{ FT } & \multicolumn{2}{c|}{ QS } & \multicolumn{2}{c|}{ IM } \\
\hline Kolbe TM Indexes & A & B & A & B & A & B & A & B \\
\hline Company 1 & 6.2 & 4.9 & 5.0 & 6.8 & 5.3 & 4.8 & 3.7 & 3.9 \\
\hline Company 2 & 4.8 & 5.5 & 5.4 & 7.0 & 5.6 & 6.3 & 4.0 & 2.8 \\
\hline Company 3 & 5.8 & 4.6 & 4.0 & 6.6 & 5.2 & 5.0 & 5.0 & 4.2 \\
\hline Company 4 & 5.9 & 3.7 & 4.7 & 5.4 & 4.1 & 4.6 & 5.3 & 6.3 \\
\hline Company 5 & 5.4 & 4.8 & 5.3 & 6.4 & 4.7 & 4.3 & 4.8 & 4.6 \\
\hline Company 6 & 6.0 & 5.5 & 4.8 & 6.5 & 4.9 & 5.2 & 4.2 & 3.4 \\
\hline Company 7 & 5.8 & 5.5 & 5.1 & 6.6 & 4.9 & 4.3 & 4.4 & 4.2 \\
\hline Company 8 & 4.4 & 4.6 & 4.2 & 5.2 & 5.4 & 6.0 & 6.4 & 5.2 \\
\hline Company 9 & 5.0 & 5.0 & 4.4 & 6.5 & 5.4 & 6.0 & 5.2 & 2.8 \\
\hline Company 10 & 6.1 & 5.0 & 5.1 & 6.6 & 5.6 & 5.7 & 3.9 & 3.3 \\
\hline Company 11 & 6.4 & 4.9 & 5.1 & 7.2 & 4.6 & 4.1 & 4.4 & 4.1 \\
\hline Mean & 5.6 & 4.9 & 4.8 & 6.4 & 5.1 & 5.1 & 4.7 & 4.1 \\
\hline Std. Dev. & 0.63 & 0.52 & 0.46 & 0.60 & 0.46 & 0.78 & 0.79 & 1.05 \\
\hline Source: Author
\end{tabular}

Source: Author

The correlation among the conative component of competencies was calculated with the Pearson Correlation Coefficient (see Table 2). 
Table 2

\section{Inter correlation of Kolbe $A^{\mathrm{TM}}$ Index values}

\begin{tabular}{|l|l|c|c|c|c|}
\cline { 3 - 6 } \multicolumn{2}{c|}{} & Ffa & Fta & Qsa & Ima \\
\hline \multirow{2}{*}{ Ffa } & Pearson Corr. & 1.000 & 0.116 & $-0.367 * *$ & $-0.416^{* *}$ \\
\cline { 3 - 6 } & Sig. (2-tailed) &. & 0.152 & 0 & 0 \\
\hline \multirow{2}{*}{ Fta } & Pearson Corr. & 0.116 & 1.000 & $-0.474^{* *}$ & $-0.173^{*}$ \\
\cline { 3 - 6 } & Sig. (2-tailed) & 0.152 &. & 0 & 0.032 \\
\hline \multirow{2}{*}{ Qsa } & Pearson Corr. & $-0.367 * *$ & $-0.474^{* *}$ & 1.000 & $-0.454^{* *}$ \\
\cline { 3 - 6 } & Sig. (2-tailed) & 0 & 0 &. & 0 \\
\cline { 3 - 6 } & Pearson Corr. & $-0.416^{* *}$ & $-0.173^{*}$ & $-0.454^{* *}$ & 1.000 \\
\cline { 3 - 6 } & Sig. (2-tailed) & 0 & 0.032 & 0 &. \\
\hline
\end{tabular}

** Correlation is significant at the 0.01 level (2-tailed).

* Correlation is significant at the 0.05 level (2-tailed).

Source: Author

Among the majority of conative components of competencies there is a negative correlation: the more distinctive the conative component is the less expressed the others are. Between Fta and Ffa is a weak positive correlation, but it is not statistically significant. The strongest correlation is between Fta and Qsa $(r=-0.474, p<0.01)$, and between Ima and Qsa ( $\mathrm{r}$ $=-0.454, \mathrm{p}<0.01)$. The correlation between Ffa and Qsa $(\mathrm{r}=-0.367)$ and Ffa and Ima $(\mathrm{r}=-$ $0.416)$ can also be confirmed. There is a weak negative correlation between Fta and Ima $(\mathrm{r}=$ $0.173 ; \mathrm{p}<0.5)$.

The Kolbe $\mathrm{B}^{\mathrm{TM}}$ Index results (see Table 3 ) are similar to the Kolbe $\mathrm{A}^{\mathrm{TM}}$ results. $\mathrm{FFb}$ and $\mathrm{FTb}$ are in a very weak positive correlation but not statistically significant (almost no correlation due to $\mathrm{r}=0.006)$. The strongest negative correlation is QSb and $\operatorname{Imb}(\mathrm{r}=-0.569$; $\mathrm{p}<0.01)$, and $\mathrm{FTb}$ and $\mathrm{QSb}(\mathrm{r}=-0.415 ; \mathrm{p}<0.01)$. A weaker negative correlation can be observed between FFb and QSb $(\mathrm{r}=-0.294 ; \mathrm{p}<0.01)$ and $\mathrm{FFb}$ and $\operatorname{Imb}(\mathrm{r}=-0.279 ; \mathrm{p}<0.01)$, and even weaker between FTb and Imb $(r=-0.199 ; \mathrm{p}<0.05)$.

Table 3

\section{Inter-correlation of Kolbe $B^{\mathrm{TM}}$ Index values}

\begin{tabular}{|c|c|c|c|c|c|}
\hline & & $\mathrm{FFb}$ & $\mathrm{FTb}$ & QSb & Imb \\
\hline \multirow{2}{*}{$\mathrm{FFb}$} & \multirow{2}{*}{$\begin{array}{l}\text { Pearson Corr. } \\
\text { Sig. (2-tailed) }\end{array}$} & 1.000 & 0.006 & $-0.294 * *$ & $-0.279 * *$ \\
\hline & & - & 0.939 & 0 & 0.001 \\
\hline \multirow{2}{*}{$\mathrm{FTb}$} & \multirow{2}{*}{$\begin{array}{l}\text { Pearson Corr. } \\
\text { Sig. (2-tailed) }\end{array}$} & 0.006 & 1.000 & $-0.415 * *$ & $-0.199 *$ \\
\hline & & 0.939 & - & 0 & 0.014 \\
\hline \multirow{2}{*}{ QSb } & \multirow{2}{*}{$\begin{array}{l}\text { Pearson Corr. } \\
\text { Sig. (2-tailed) }\end{array}$} & $-0.294 * *$ & $-0.415^{* *}$ & 1.000 & $-0.569 * *$ \\
\hline & & 0 & 0 & . & 0 \\
\hline \multirow{2}{*}{$\operatorname{Imb}$} & \multirow{2}{*}{$\begin{array}{l}\text { Pearson Corr. } \\
\text { Sig. (2-tailed) }\end{array}$} & $-0.279 * *$ & $-0.199 *$ & $-0.569 * *$ & 1.000 \\
\hline & & 0.001 & 0.014 & 0 & \\
\hline
\end{tabular}

** Correlation is significant at the 0.01 level (2-tailed).

* Correlation is significant at the 0.05 level (2-tailed).

Source: Author 
FTb has the highest average value and Ima has the lowest. Only the mean FTb Kolbe $\mathrm{B}^{\mathrm{TM}}$ Index is higher than the mean Kolbe $\mathrm{A}^{\mathrm{TM}}$ Index; all others are lower. The IM and QS results match most, while the correlation is weak in the case of FF and FT ( 0.2 or less).

As shown in Table 4, the differences in mean values are statistically important only in the case of the pairs FF and FT (the mean value Ffa is higher than FFb and the mean value $\mathrm{FTb}$ is higher than Fta).

Table 4

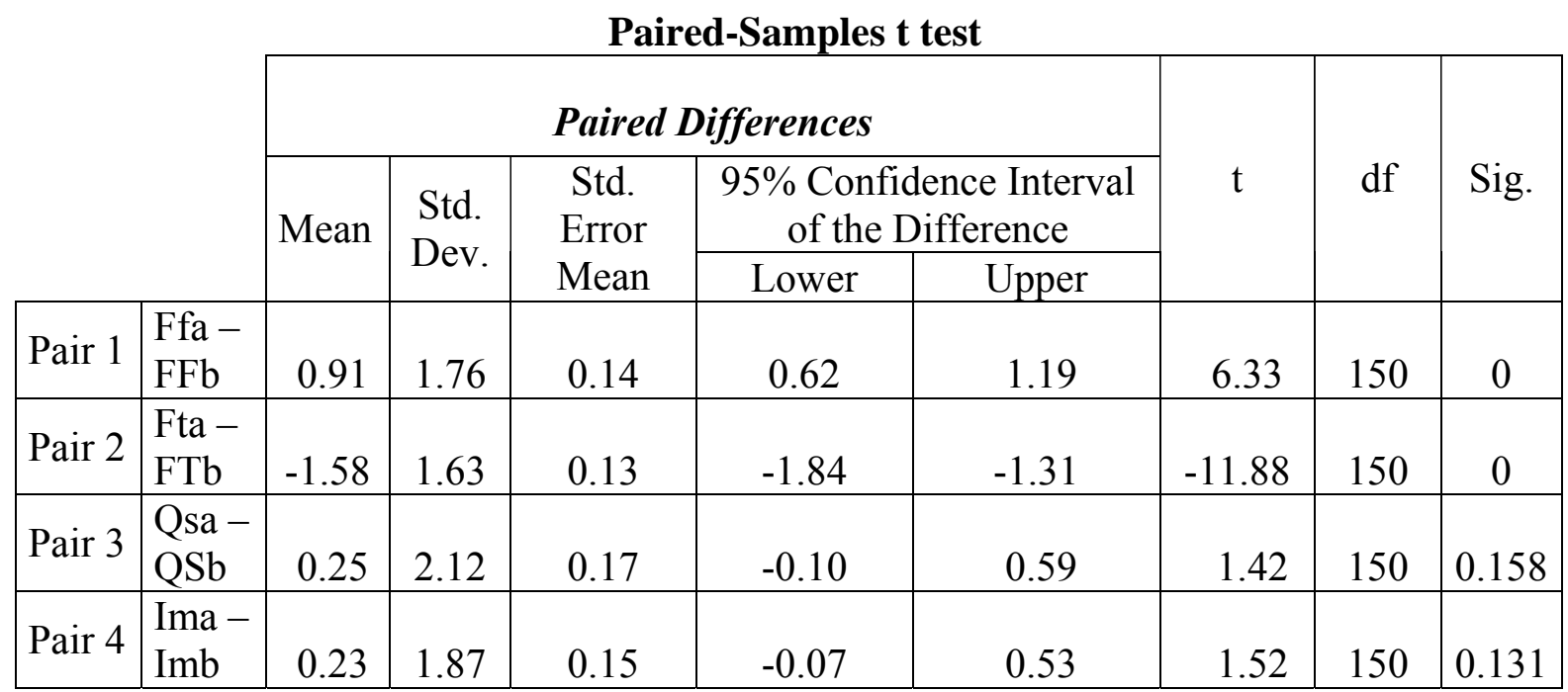

Source: Author

\section{Findings and discussion}

The mean values at the company level were, according to normal distribution, expected. A comparison of the Kolbe $\mathrm{A}^{\mathrm{TM}}$ and Kolbe $\mathrm{B}^{\mathrm{TM}}$ Index values suggests that managers are inclined to analyze, quantify and compare results from the past, but their focus on details is not as great as their natural ability (the mean value for the FF Kolbe $\mathrm{A}^{\mathrm{TM}}$ Index is 5.6 and for the Kolbe $\mathrm{B}^{\mathrm{TM}}$ Index it is 4.9). On the other hand, they like to follow existing procedures, plan and perform routine work (the mean value for the FT Kolbe $\mathrm{A}^{\mathrm{TM}}$ Index is 4.8 and for the Kolbe $\mathrm{B}^{\mathrm{TM}}$ Index it is 6.4). Their conative component of competencies and their view of how they should actually use it are at the same level (the mean value for the QS Kolbe $\mathrm{A}^{\mathrm{TM}}$ Index is 5.1 and for the Kolbe $\mathrm{B}^{\mathrm{TM}}$ Index it is 5.1), meaning that the result is in the accommodating zone.

When comparing the conative component of competencies on the individual level we found a negative correlation: the more distinctive the conative component is, the less expressed are the others. The highest negative correlation is detected in the Kolbe $\mathrm{A}^{\mathrm{TM}}$ Index FT and QS values, meaning the more planning and routine work, the less opportunity spotting, innovating and risk taking. Similarly high is the negative correlation between the Kolbe $\mathrm{A}^{\mathrm{TM}}$ Index FF and QS values, meaning the more analyzing, quantifying and focusing on details there is, the worse the ability is to spot and use opportunities, innovate, risk and find new solutions. Thus, Hypothesis 1 is confirmed.

It was observed that each of the Kolbe $\mathrm{A}^{\mathrm{TM}}$ Index values on the individual level is higher than the Kolbe $\mathrm{B}^{\mathrm{TM}}$ Index value, except for the FT value. It could be claimed that middle managers have a natural knack for analyzing, quantifying, comparing past results, and 
focusing on details, but are less prone to more aggressive risk-taking than they believe themselves to be. Measurement of their conative component of competency in the QS mode suggests that they have a greater natural knack for invention, brainstorming, origination, challenge, risk-taking, reform, improvisation, and promotion than perceived and exercised in practice. Hence, Hypothesis 2 is confirmed as well.

The correlations of pair samples reveal that managers have the most difficulties in accommodating the QS and IM modes. It could be concluded that they would adapt in the case of opportunities and take advantage of them, but they would most likely not take the initiative.

\section{FUTURE RESEARCH AND CONCLUSION}

The results of the study should be interpreted with caution due to the size of the sample and the measurement of the constructs. The sample of managers of SMEs in the post-transitional economy of Slovenia might be different from samples of their peers in developed market economies, which may impact the results. Interpretation of our analyses should take into account that only representatives of some sectors were analyzed and thus should be interpreted with care. The results from SMEs from different sectors may be different. The evolving market economy of Slovenia requires different conative competencies from those valued and required in Slovenia's previous socio-economic system with less accommodation and more initiative taking. However, Slovenia can provide a small-scale role model for other transition economies in the region which aspire to enter the EU, moreover, it can be a valuable case to other developing economies worldwide on their way to market economies. Further studies are required in order to corroborate the results, which might be affected by the cultural context and not be extrapolated to other contexts. Despite these limitations, the authors believe that the study helps to better understand competency in general and provides insightful directions for advanced studies in this area.

Moreover, the presented method, being quantitative, provides a framework for a promising investigation of inborn, un-teachable managerial antecedents. However, emphasis should be placed on further longitudinal and international studies. It would be particularly interesting for future research to make comparisons between peers in countries that are more developed than Slovenia.

The study suggests that Slovene managers are not aggressive initiative-takers, but do not resist opportunities when they arise. On the other hand, it seems that historical and other socio-economic circumstances in Slovenia influenced managers in the way that they have become more obedient and adaptable. Due to that reason, a longitudinal study is suggested for future research to analyze changes which have been made among Slovene managers and to justify the presented results.

\section{IN MEMORIAM}

I would like to dedicate this paper to Darko Kovač (1957-2009) for his contribution to the study of managerial competencies in Slovenia. 


\section{REFERENCES}

Armstrong, M., (2003), A Hand Book of Human Resource Management Practice, $9^{\text {th }}$ ed., (London: Kogan Page Limited).

Baker, J.C., Mapes, J., New C.C., Szwejczewski, M., (1997), "A hierarchical model of business competence", Integrated Manufacturing Systems, 8 (5): 265-272.

Baumeister, R.F., Bratslavsky, E., Muraven, M., Tice, M.M., (1998), "Ego depletion: Is the active self a limited resource?", Journal of Personality and Social Psychology, 74: 12521265.

Biloslavo, R., Lynn, M.L., (2007),'Mission statements in Slovene enterprises: institutional pressures and contextual adaption", Management Decision, 45(4): 773-788.

Boon, J., Van der Klink, M., (2002), "Competencies: The triumph of a fuzzy concept", Academy of Human Resource Development Annual Conference, Honolulu, HA, 27 February- 3 March, Proceedings, 1: 327-334.

Boyatzis, R., (1982), The Competent Manager,( New York: Wiley \& Sons).

Burgoyne, J., (1993), "The competence movement: issues, stakeholders and prospects", Personnel Management, 22: 6-13.

Chung, Q.B., Luo, W., Wagner,W.P., (2006), "Strategic alliances of small firms in knowledge industries", Business Process Management Journal, 12 (2): 206-233.

Cheetham, G., Chivers, G., (1996), "Towards a holistic model of professional competence", Journal of European Industrial Training, 20: 20-31.

Dolenc, P., (2010), "Privatization in a post-communist economy:it seems there are no macroeconomic effects", Ekonomska istraživanja, 23(1): 60-72.

Draganidis, F., Mentzas, G., (2006), "Competency based management: a review of systems and approaches", Information Management and Computer Security, 14: 51-64.

Earley, P.C., Ang, S., (2003), Cultural Intelligence: Individual Interactions Across Cultures, (Stanford: Stanford University Press).

Ellström, P-E., (1999), Integrating learning and work: problems and prospects, Contribution to the FORUM Workshop: Learning in Learning Organizations, Evora: University of Evora, Portugal.

Emmons, R., (1986), "Personal strivings: an approach to personality and subjective wellbeing", Journal of Personality and Social Psychology, 51: 1058-1068.

Garavan, T.N., McGuire, D., (2001), "Competencies and workplace learning: some reflections on the rhetoric and the reality", Journal of Workplace Learning, 13: 144-163.

Grigorenko, E.L., Sternberg, R.J., Ehrman, M.E., (2000), "A theory-based approach to the measurement of foreign language learning ability: The CANAL-F theory and test", The Modern Language Journal, 84: 390-405.

Hoffmann, T., (1999), "The meanings of competency", Journal of European Industrial Training, 23: 275-85.

Kane, R., (1985), Free will and values, ( Albany: State University of New York Press).

Kolbe, K., (1997), The conative connection, (Beverly: Addison-Wesley Publishing Company, Inc).

Kolbe Corporation, (1999), Kolbe bottom lines, ( Phoenix: Kolbe Corporation).

Kolbe, K., (2003), Kolbe Statistical Handbook, (Phoenix: Kolbe Corporation).

Kolbe, K., (2004), Powered by Instinct: 5 Rules for Trusting Your Guts, (Phoenix, AZ: Monumentus Press).

Kovač, D., Bertoncelj, A., (2008),“Organizational mental map and conative competences”, Organizacija - Journal of Management, Informatics and Human Resources, 41: 127-135.

Liu, X., Ruan, D., Xu, Y. (2005) A study of enterprise human resource competence appraisement. The Journal of Enterprise Information Management, 18: 289-315. 
McClelland, D.C., (1973), "Testing for competence rather than for intelligence", American Psychologist, 28: 1-14.

McClelland, D.C., (1998), "Identifying competencies with behavioural-event interviews", Psychological Science, 9: 331-339.

Mischel, W., (1996), From good intentions to willpower, In: Gollwitzer, P., Bargh, J. (Eds), The psychology of action, pp.197-218, New York: Guilford Press.

Mlinar,S., Videmšek,M., Meško,M., Karpljuk,D.,(2009), “Self-estimated stress experience and health status of the casino employees", Zdravstveno varstvo, 48 (3):105-113.

Mulder, M., Collins, C., (2007), "Competence Development in Organisations: Its Use in Practice", Annual Meeting of the AERA, Wageningen: Wageningen University, (Retrieved on 26.6.2009: http://www.mmulder.nl).

Patel, T., (2007), "The role of dynamic cultural theories in explaining the viability of international strategic alliances", Management Decision, 45(10): 1532-1559.

Rogoff, B., (1990), Apprenticeship in thinking. Cognitive development in social context, (New York: Oxford University Press).

Ruth, D., (2006), "Frameworks of managerial competence: limits, problems and suggestions", Journal of European Industrial Training, 30 (3): 206-226.

Sandberg, J., (2000), "Understanding human competence at work: an interpretative approach", Academy of Management Journal, 43: 9-25.

Schroder, H.M., (1989), Managerial Competence: The Key to Excellence, (Iowa, Kendall/Hunt).

Selby, S.C., Roos, I., Wright, L., (2000), Investigation of the application of frontline management training in the community services and health industry: a progress report, Paper presented at the Victorian Community Services and Health Industry Training Board Conference, Melbourne.

Snow, R.E., Corno L., Jackson, D., (1996), Individual differences in affective and conative functions, In: Berlinger and Calfee (eds.), Handbook of educational psychology, pp. 243310, New York: Simon \& Schuster Macmillan.

Videmšek, M., Karpljuk, D., Mlinar, S., Meško, M., Štihec, J., (2010), “Injuries to primary school pupils and secondary school students during physical education classes and their leisure time", Collegium antropologica, 34 (3): 973-980.

Vroom, V.H., (1964), Work and Motivation, (New York: Wiley\&Sons).

Winterton, J., Delamare-Le Deist, F., Stringfellow, E., (2005), Typology of knowledge, skills and competences: clarification of the concept and prototype, Research report elaborated on behalf of Cedefop/Thessaloniki, CEDEFOP, Project No RP/B/BS/Credit Transfer/005/04).

Yang, B-C., Wu, B-E., Shu, P-G, Yang, M-H., (2006), "On establishing the core competency identifying model, A value-activity and process oriented approach", Industrial Management \& Data Systems, 106: 60-80. 


\title{
OKVIR MENADŽERSKIH NADLEŽNOSTI: STUDIJA KONATIVNE KOMPONENTE
}

\begin{abstract}
SAŽETAK
Cilj ovog rada jest proučavanje konativne nadležnosti menadžera u tranzicijskoj ekonomiji Slovenije. Konceptualni okvir trojnih komponenata nadležnosti temelji se na uzorku od 183 menadžera u 11 malih i srednjih poduzeća različitih industrijskih sektora. Proučena su eventualna nepodudaranja između menadžerske konativne komponente, njihovih osobnih očekivanja i razine prilagođavanja. Studija dokazuje da slovenski menadžeri nisu dovoljno agresivni u preuzimanju inicijativa, ali ne mogu odoljeti novim prilikama. Međutim, konativna komponenta ukazuje na njihove poteškoće u suočavanju s tržišnim i ekonomskim izazovima, s obzirom na pomalo stidljivi pristup u pronalaženju novih mogućnosti.
\end{abstract}

Ključne riječi: Motivacija, okvir trojnih komponenata nadležnosti, MSP, srednji menadžeri, Slovenija. 